Article

\title{
$\alpha$-Pyrone Polyketides from Streptomyces ambofaciens BI0048, an Endophytic Actinobacterial Strain Isolated from the Red Alga Laurencia glandulifera
}

\author{
Enikő Rab ${ }^{1}$, , Dimitrios Kekos ${ }^{2}$, Vassilios Roussis ${ }^{1}$ and Efstathia Ioannou ${ }^{1, *}$ \\ 1 Section of Pharmacognosy and Chemistry of Natural Products, Department of Pharmacy, \\ School of Health Sciences, National and Kapodistrian University of Athens, Panepistimiopolis Zografou, \\ 15771 Athens, Greece; rabeniko@gmail.com (E.R.); roussis@pharm.uoa.gr (V.R.) \\ 2 Laboratory of Biotechnology, School of Chemical Engineering, National Technical University of Athens, \\ 9 Iroon Polytechniou Str., Zografou Campus, 15780 Athens, Greece; kekos@chemeng.ntua.gr \\ * Correspondence: eioannou@pharm.uoa.gr; Tel.: +30-210-727-4913
}

Received: 2 November 2017; Accepted: 7 December 2017; Published: 14 December 2017

\begin{abstract}
Four new (1-4) and six previously reported (5-10) $\alpha$-pyrone polyketides, along with benzoic acid, hydrocinnamic acid, and $(E)$-cinnamic acid, were isolated from the organic extract resulting from the cultivation of the algicolous strain Streptomyces ambofaciens BI0048, which in turn was isolated from the inner tissues of the red alga Laurencia glandulifera. The structure elucidation of the isolated natural products was based on extensive analysis of their spectroscopic data (NMR, MS, UV, IR). Compounds 1-10 were evaluated for their antibacterial and cytotoxic activities against two multidrug-resistant strains of Staphylococcus aureus and one strain of Escherichia coli, as well as two human cancer cell lines.
\end{abstract}

Keywords: Streptomyces ambofaciens; algicolous actinobacterium; endophytic strain; polyketides; $\alpha$-pyrone; structure elucidation; bioactivity evaluation

\section{Introduction}

The screening of microbial natural products represents an important route to the discovery of novel anticancer and antibiotic agents [1-3]. Diverse actinobacteria isolated from unique ecosystems have been shown to produce bioactive compounds, which exert their influence by mechanisms that are not compromised by existing multidrug-resistance pathways [4].

In order to obtain new strains likely to produce novel metabolites, investigation of samples from different habitats and extreme environments is necessary. The East Mediterranean basin is a geomorphologically and biologically unique marine ecosystem that has not been examined so far for its microbiota as producers of secondary metabolites.

In search of new bioactive secondary metabolites from marine organisms of the Greek seas, we have recently expanded our research interests in marine-derived microbiota. To this end, we have selectively isolated more than 900 actinobacterial strains from marine sediments and marine macroorganisms collected from the Aegean and the Ionian Seas.

On the basis of preliminary screening of the chemical profiles of extracts obtained from small-scale liquid cultures of numerous actinobacterial strains with LC-DAD-MS and NMR in conjunction with the results of the evaluation of their antibacterial and cytotoxic activities, strain BI0048, isolated from the inner tissues of the red alga Laurencia glandulifera, was selected for further chemical investigation. The algicolous endophytic strain, which was identified as Streptomyces ambofaciens, was cultured in large-scale in flasks containing a seawater-based liquid medium and the resulting organic residue 
derived from its extraction was subjected to a multi-step fractionation scheme that led to the isolation of a number of secondary metabolites.

Herein, we report the isolation and structure elucidation of four new (1-4) and six previously reported (5-10) $\alpha$-pyrone polyketides (Figure 1) and the evaluation of their antibacterial and cytotoxic activities.
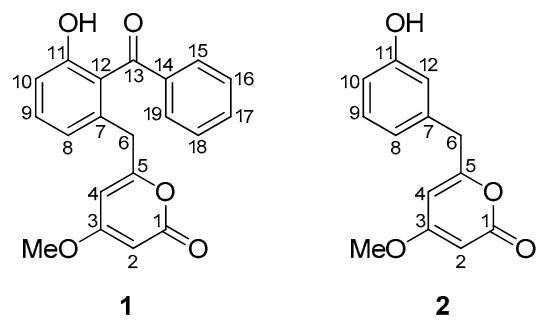

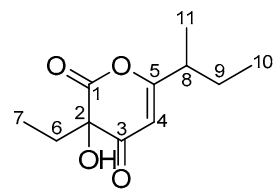

3<smiles>[3H]C[C@@]1(O)C(=O)C=C(C(C)C)OC1=O</smiles>

4<smiles>O=C1C[C@@](O)(c2ccccc2)[C@H](c2cc(O)cc(=O)o2)c2cccc(O)c21</smiles>

5<smiles>O=C1C[C@@](O)(c2ccccc2)[C@H](c2cc(O)cc(=O)o2)c2cccc(O)c21</smiles>

6

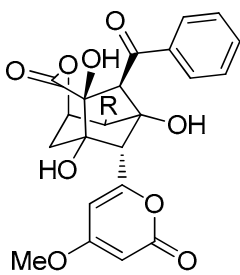

$7 \mathrm{R}=\mathrm{OH}$ $8 \mathrm{R}=\mathrm{H}$<smiles>CCc1c(O)cc(C(C)CC)oc1=O</smiles>

9<smiles>CCc1c(O)cc(C(C)C)oc1=O</smiles>

10

Figure 1. Chemical structures of compounds 1-10 isolated from the algicolous endophytic strain Streptomyces ambofaciens BI0048.

\section{Results and Discussion}

The organic extract resulting from the cultivation of the algicolous endophytic strain S. ambofaciens BI0048 was subjected to repetitive chromatographic fractionations and HPLC purifications to afford the new $\alpha$-pyrone polyketides 1-4 and nine previously reported metabolites, which were identified as wailupemycin D (5), wailupemycin E (6), enterocin, also known as vulgamycin (7), 5-deoxy-enterocin (8), germicidin A (9), germicidin B (10), benzoic acid, hydrocinnamic acid, and $(E)$-cinnamic acid by comparison of their spectroscopic and physical characteristics with those reported in the literature [5-11].

Zoumbericin A (1), isolated as a colorless oil, displayed an ion peak at $m / z 335.0928$ (HRESIMS), corresponding to $\mathrm{C}_{20} \mathrm{H}_{15} \mathrm{O}_{5}$ and consistent with $[\mathrm{M}-\mathrm{H}]^{-}$. The ${ }^{13} \mathrm{C}$ NMR spectrum (Table 1 ) revealed 20 carbon signals, which corresponded to eight non-protonated carbon atoms, among which two carbonyls at $\delta_{C} 165.2$ and 199.2, ten methines, one methylene and one methyl, as determined from DEPT experiments. The ${ }^{1} \mathrm{H}$ NMR spectrum (Table 1) included signals at $\delta_{\mathrm{H}} 6.87(1 \mathrm{H}, \mathrm{d}, 7.5 \mathrm{~Hz})$, $7.36(1 \mathrm{H}, \mathrm{dd}, 8.2,7.5 \mathrm{~Hz})$ and $6.95(1 \mathrm{H}, \mathrm{d}, 8.2 \mathrm{~Hz})$ indicative of a 1,2,3-trisubstituted aromatic ring, as well as at $\delta_{\mathrm{H}} 7.67(2 \mathrm{H}, \mathrm{d}, 8.3 \mathrm{~Hz}), 7.43(2 \mathrm{H}, \mathrm{dd}, 8.3,7.4 \mathrm{~Hz})$ and $7.57(1 \mathrm{H}, \mathrm{t}, 7.4 \mathrm{~Hz})$ pointing to the presence of a monosubstituted aromatic ring. Furthermore, the ${ }^{1} \mathrm{H}$ NMR spectrum of 1 exhibited signals for a deshielded methylene at $\delta_{\mathrm{H}} 3.52$, a methoxy group at $\delta_{\mathrm{H}} 3.69$, and two methines at $\delta_{\mathrm{H}} 5.27$ and 5.43. In agreement with the literature $[8,9,12]$, the latter three signals, in conjunction with the ${ }^{13} \mathrm{C}$ NMR resonances of $C-1\left(\delta_{C} 165.2\right), C-2\left(\delta_{C} 87.8\right), C-3\left(\delta_{C} 170.9\right), C-4\left(\delta_{C} 101.3\right)$ and C-5 $\left(\delta_{C} 162.8\right)$, were characteristic for a 4,6-disubstituted 4-methoxy- $\alpha$-pyrone ring, present also in the co-occurring enterocin (7) and 5-deoxy-enterocin (8). The absorption band at $1687 \mathrm{~cm}^{-1}$ and the maximum absorbance at $282 \mathrm{~nm}$ observed in the IR and UV spectra of 1, respectively, further supported the presence of the $\alpha$-pyrone ring in the molecule. The HMBC correlations of $\mathrm{H}_{2}-6$ to $\mathrm{C}-4$, C-5, C-7, C-8 and C-12 suggested the linkage of the $\alpha$-pyrone ring to the 1,2,3-trisubstituted aromatic ring through C-6, while the monosubstituted aromatic ring was linked to the latter through C-13 
(Figure 2). This hypothesis was further supported by the fragment ions at $m / z 105$ and 259 observed in the EIMS of $\mathbf{1}$, corresponding to the phenylketone moiety $\left(\left[\mathrm{C}_{7} \mathrm{H}_{5} \mathrm{O}\right]^{+}\right)$and $\left[\mathrm{C}_{14} \mathrm{H}_{11} \mathrm{O}_{5}\right]^{+}$resulting from the cleavage of the phenyl group.

Table 1. ${ }^{1} \mathrm{H}(400 \mathrm{MHz})$ and ${ }^{13} \mathrm{C}(50 \mathrm{MHz}) \mathrm{NMR}$ data in $\mathrm{CDCl}_{3}$ of compounds $\mathbf{1}$ and 2.

\begin{tabular}{|c|c|c|c|c|}
\hline \multirow{2}{*}{ Position } & \multicolumn{2}{|r|}{1} & \multicolumn{2}{|c|}{2} \\
\hline & $\delta_{\mathrm{C}}$ & $\delta_{\mathrm{H}}(J$ in $\mathrm{Hz})$ & $\delta_{\mathrm{C}}$ & $\delta_{\mathrm{H}}(J$ in $\mathrm{Hz})$ \\
\hline 1 & $165.2, C^{1}$ & - & $165.0, C^{1}$ & - \\
\hline 2 & $87.8, \mathrm{CH}$ & $5.27, \mathrm{~d}(2.2)$ & $87.7, \mathrm{CH}$ & $5.39, \mathrm{~d}(2.2)$ \\
\hline 3 & $170.9, \mathrm{C}$ & - & $171.3, \mathrm{C}$ & - \\
\hline 4 & $101.3, \mathrm{CH}$ & $5.43, \mathrm{~d}(2.2)$ & $100.7, \mathrm{CH}$ & $5.68, \mathrm{~d}(2.2)$ \\
\hline 5 & $162.8, \mathrm{C}$ & - & $164.2, \mathrm{C}$ & - \\
\hline 6 & $38.3, \mathrm{CH}_{2}$ & $3.52, \mathrm{~s}$ & 39.7, $\mathrm{CH}_{2}$ & $3.67, \mathrm{~s}$ \\
\hline 7 & $134.4, C^{1}$ & - & $136.5, \mathrm{C}$ & - \\
\hline 8 & $123.2, \mathrm{CH}$ & $6.87, \mathrm{~d}(7.5)$ & $121.5, \mathrm{CH}$ & 6.78, brd $(7.5)$ \\
\hline 9 & $133.0, \mathrm{CH}$ & $7.36, \mathrm{dd}(8.2,7.5)$ & $130.0, \mathrm{CH}$ & $7.17, \mathrm{t}(7.5)$ \\
\hline 10 & $116.7, \mathrm{CH}$ & $6.95, \mathrm{~d}(8.2)$ & $114.5, \mathrm{CH}$ & $6.74, \mathrm{~m}$ \\
\hline 11 & 157.0, $\mathrm{C}^{1}$ & - & $156.0, C^{1}$ & - \\
\hline 12 & $123.7, C^{1}$ & - & $116.2, \mathrm{CH}$ & $6.73, \mathrm{~d}(1.0)$ \\
\hline 13 & $199.2, C^{1}$ & - & - & - \\
\hline 14 & $138.2, C^{1}$ & - & - & - \\
\hline 15 & $129.1, \mathrm{CH}$ & $7.67, \mathrm{~d}(8.3)$ & - & - \\
\hline 16 & $128.9, \mathrm{CH}$ & $7.43, \mathrm{dd}(8.3,7.4)$ & - & - \\
\hline 17 & $133.6, \mathrm{CH}$ & $7.57, \mathrm{t}(7.4)$ & - & - \\
\hline 18 & $128.9, \mathrm{CH}$ & $7.43, \mathrm{dd}(8.3,7.4)$ & - & - \\
\hline 19 & $129.1, \mathrm{CH}$ & $7.67, \mathrm{~d}(8.3)$ & - & - \\
\hline $\mathrm{OMe}$ & $55.8, \mathrm{CH}_{3}$ & $3.69, \mathrm{~s}$ & $55.9, \mathrm{CH}_{3}$ & $3.75, \mathrm{~s}$ \\
\hline $\mathrm{OH}$ & - & 7.80, brs & - & - \\
\hline
\end{tabular}

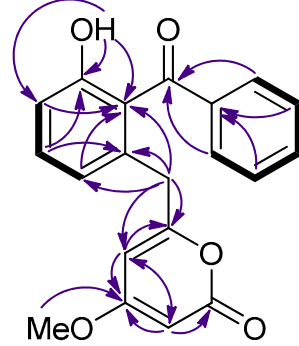

1

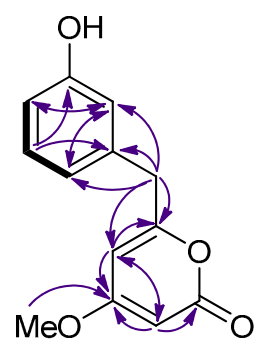

2

Figure 2. COSY (bold bonds) and important HMBC (arrows) correlations observed for compounds 1 and 2.

Zoumbericin B (2), obtained as a colorless oil, had the molecular formula $\mathrm{C}_{13} \mathrm{H}_{12} \mathrm{O}_{4}$, as calculated from the HRESIMS measurements and NMR data. The spectroscopic characteristics of 2 were similar to those of metabolite $\mathbf{1}$. Specifically, as in the case of $\mathbf{1}$, the ${ }^{1} \mathrm{H}$ and ${ }^{13} \mathrm{C}$ NMR spectroscopic data of compound 2 (Table 1 ) included signals for a 4,6-disubstituted 4-methoxy- $\alpha$-pyrone moiety and a deshielded methylene resonating at $\delta_{\mathrm{H}} 3.67$ as a singlet. However, in contrast to 1 , the only other signals present in the NMR spectra of 2 were those attributed to a 1,3-disubstituted aromatic ring. The COSY and HMBC correlations observed for $\mathbf{2}$ (Figure 2) allowed for the unambiguous identification of the 4-methoxy- $\alpha$-pyrone and the aromatic ring which were connected through C-6. 
Germicidin K (3), isolated as a colorless oil, displayed an ion peak at $m / z 211.0975$ (HRESIMS), corresponding to $\mathrm{C}_{11} \mathrm{H}_{15} \mathrm{O}_{4}$ and consistent with $[\mathrm{M}-\mathrm{H}]^{-}$. The ${ }^{1} \mathrm{H}$ NMR data of 3 (Table 2), including signals for two aliphatic methyls on secondary carbons $\left(\delta_{\mathrm{H}} 0.92\right.$ and 0.97$)$, one aliphatic methyl on a tertiary carbon $\left(\delta_{\mathrm{H}} 1.20\right)$, two methylenes $\left(\delta_{\mathrm{H}} 1.54 / 1.68\right.$ and 1.98), one relatively deshielded methine $\left(\delta_{\mathrm{H}} 2.41\right)$ and one olefinic methine $\left(\delta_{\mathrm{H}} 5.68\right)$, were rather similar to those of the co-occurring germicidin A (9). Indeed, the ${ }^{13} \mathrm{C}$ NMR spectrum of 3 exhibited 11 carbon signals, which, according to the DEPT experiments, were attributed to three methyls, two methylenes, two methines, and four quaternary carbon atoms. However, in contrast to germicidin A (9), which exhibits signals for one carbonyl $\left(\delta_{C} 167.5\right)$ and four olefinic carbons $\left(\delta_{C} 99.6,104.7,165.9\right.$ and 167.2) [10], resonances for two carbonyls $\left(\delta_{C} 167.2\right.$ and 191.2$)$, two olefinic carbons $\left(\delta_{C} 104.6\right.$ and 175.3$)$ and one oxygenated quaternary carbon $\left(\delta_{C} 91.7\right)$ were evident for compound 3 (Table 2). The structure of germicidin $\mathrm{K}(3)$ was proposed on the basis of the correlations observed in its 2D NMR spectra, as depicted in Figure 3. Due to the limited amount in which 3 was isolated, it was not possible to determine the absolute configuration at C-2 and C-8.

Table 2. ${ }^{1} \mathrm{H}(400 \mathrm{MHz})$ and ${ }^{13} \mathrm{C}(50 \mathrm{MHz}) \mathrm{NMR}$ data in $\mathrm{CDCl}_{3}$ of compounds 3 and 4 .

\begin{tabular}{|c|c|c|c|c|}
\hline \multirow{2}{*}{ Position } & \multicolumn{2}{|c|}{3} & \multicolumn{2}{|c|}{4} \\
\hline & $\delta_{\mathrm{C}}$ & $\delta_{\mathbf{H}}(J$ in $\mathbf{H z})$ & $\delta_{\mathrm{C}}$ & $\delta_{\mathbf{H}}(J$ in $\mathbf{H z})$ \\
\hline 1 & $167.2, C^{1}$ & - & 167.6, C & - \\
\hline 2 & 91.7, C & - & $91.7, \mathrm{C}$ & - \\
\hline 3 & 191.2, C & - & 191.3, C & - \\
\hline 4 & 104.6, CH & $5.68, \mathrm{~s}$ & 103.3, CH & $5.69, \mathrm{~s}$ \\
\hline 5 & $175.3, \mathrm{C}$ & - & $176.2, \mathrm{C}$ & - \\
\hline 6 & $30.7, \mathrm{CH}_{2}$ & $1.98, \mathrm{q}(7.6)$ & $30.7, \mathrm{CH}_{2}$ & 1.98, q (7.6) \\
\hline 7 & $7.3, \mathrm{CH}_{3}$ & $0.97, \mathrm{t}(7.6)$ & 7.3, $\mathrm{CH}_{3}$ & $0.96, \mathrm{t}(7.6)$ \\
\hline 8 & $40.2, \mathrm{CH}$ & $2.41, \mathrm{~m}$ & 33.0, CH & 2.64 , septet $(6.8)$ \\
\hline 9 & 26.5, $\mathrm{CH}_{2}$ & $1.68, \mathrm{~m}, 1.54, \mathrm{~m}$ & $19.2, \mathrm{CH}_{3}$ & $1.22, \mathrm{~d}(6.8)$ \\
\hline 10 & $11.4, \mathrm{CH}_{3}$ & $0.92, \mathrm{t}(7.4)$ & $19.3, \mathrm{CH}_{3}$ & $1.23, \mathrm{~d}(6.8)$ \\
\hline 11 & $17.1, \mathrm{CH}_{3}$ & $1.20, \mathrm{~d}(6.9)$ & - & - \\
\hline $\mathrm{OH}$ & - & 9.36, brs & - & 9.35, brs \\
\hline
\end{tabular}

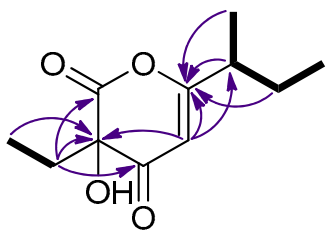

3

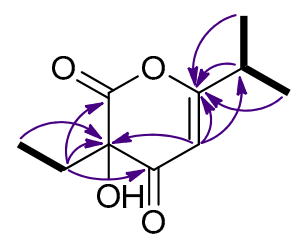

4

Figure 3. COSY (bold bonds) and important HMBC (arrows) correlations observed for compounds 3 and 4 .

Germicidin $\mathrm{L}$ (4), with the molecular formula $\mathrm{C}_{10} \mathrm{H}_{14} \mathrm{O}_{4}$, as deduced from the HRESIMS measurements where an ion peak consistent with $[\mathrm{M}-\mathrm{H}]^{-}$was observed at $\mathrm{m} / z$ 197.0818, was obtained as a colorless oil. Its ${ }^{1} \mathrm{H}$ and ${ }^{13} \mathrm{C}$ NMR spectroscopic data (Table 2) closely resembled those of $\mathbf{3}$ and the co-occurring germicidin B (10), with the most prominent differences between $\mathbf{3}$ and 4 being the presence of a second aliphatic methyl on a tertiary carbon and the simultaneous absence of an aliphatic methyl on a secondary carbon and a methylene. As in the case of 3 , the ${ }^{13} \mathrm{C} N M R$ spectrum of 4 included signals for two carbonyls $\left(\delta_{C} 167.6\right.$ and 191.3), two olefinic carbons $\left(\delta_{C} 103.3\right.$ and 176.2) and one oxygenated quaternary carbon $\left(\delta_{C} 91.7\right)$, instead of one carbonyl $\left(\delta_{C} 168.2\right)$ and four olefinic 
carbons $\left(\delta_{C} 98.6,104.7,166.5\right.$ and 167.8), as observed for germicidin B (10) [10]. The COSY cross-peaks and the HMBC correlations, as depicted in Figure 3, supported the proposed structure of germicidin L (4). Similarly, since 4 was isolated in limited amount, the absolute configuration at C-2 could not be established.

The $\alpha$-pyrone moiety constitutes an essential pharmacophore in many naturally occurring and synthetic bioactive compounds. Natural products featuring a $\alpha$-pyrone ring are often involved in defense processes, while frequently they possess antibacterial, antifungal, antiviral, cytotoxic, phytotoxic and neurotoxic properties [13,14]. In 1976, when initially isolated and characterized, enterocin (7) was reported to be bacteriostatic in a disk-diffusion assay at a concentration of $4 \mathrm{mg} / \mathrm{mL}$ against Gram-positive and Gram-negative bacteria, including strains of Escherichia coli, Proteus vulgaris, Sarcina lutea, Staphylococcus aureus and Corynebacterium xerosis, but showed no activity against strains of Bacillus subtilis, Bacillus megaterium, Pseudomonas aeruginosa, Candida albicans and Penicillium chrysogenum [7]. In a subsequent study, enterocin (7) did not exhibit any activity against strains of S. aureus, B. subtilis, P. aeruginosa, Salmonella typhimurium, E. coli, Saccharomyces cerevisiae, C. albicans, P. chrysogenum and Trichophyton mentagrophytes and displayed weak activity only against a strain of Micrococcus luteus [15]. In addition, enterocin (7) exhibited herbicidal activity when applied post-emergence, controlling dicotyledonous weeds and grasses at dosages between 125 and $500 \mathrm{~g} \mathrm{ha}^{-1}$, being safe for application on cotton, maize and barley [16]. 5-Deoxy-enterocin (8) was reported to inhibit strains of S. lutea, S. aureus, Klebsiella pneumoniae and Vibrio percolans at a concentration of $0.5 \mathrm{mg} / \mathrm{mL}$ [9]. Germicidin A (9), the first known autoregulative inhibitor of spore germination in the genus Streptomyces, has been shown to have an inhibitory effect on the germination of Streptomyces arthrospores at concentrations as low as $40 \mathrm{pg} / \mathrm{mL}$, while at higher concentrations it inhibited porcine $\mathrm{Na}^{+} / \mathrm{K}^{+}$-activated ATPase and retarded the germination of the cress Lepidium sativum. In contrast, germicidin B (10) did not show any activity in the same germination and ATPase assays [10]. Moreover, germicidin A (9) exhibited weak activity against strains of Streptomyces viridochromogenes and Streptomyces griseus, but did not inhibit the growth of other Gram-positive and Gram-negative bacteria and several fungi and showed no effect on the mobility of the nematode Caenorabditis elegans [10]. Furthermore, germicidins A (9) and B (10) were proven inactive in a disk-diffusion assay against strains of B. subtilis, Mycobacterium vaccae, P. aeruginosa, methicillin-resistant $S$. aureus, vancomycin-resistant Enterococcus faecalis and Sporobolomyces salmonicolor [17].

Compounds 1-10 were evaluated for their antibacterial activities against the epidemic methicillin-resistant strain EMRSA-15 and the multidrug-resistant effluxing strain SA1199B of S. aureus, as well as the E. coli strain NCTC-10418. Furthermore, the cytotoxic activities of 1-10 were tested against the MCF7 (breast adenocarcinoma) and A549 (lung carcinoma) human cancer cell lines. However, metabolites 1-10 were proven inactive in both bioactivity assays.

\section{Materials and Methods}

\subsection{General Experimental Procedures}

Optical rotations were measured on a Perkin Elmer model 341 polarimeter (PerkinElmer Instruments, Norwalk, CT, USA) with a $1 \mathrm{dm}$ cell. UV spectra were obtained on a Perkin Elmer Lambda 40 spectrophotometer (PerkinElmer Ltd., Buckinghamshire, UK). IR spectra were obtained on a Bruker Tensor 27 spectrometer (Bruker Optik GmbH, Ettlingen, Germany). NMR spectra were recorded on Bruker AC 200 and Bruker DRX 400 spectrometers (Bruker BioSpin GmbH, Rheinstetten, Germany). Chemical shifts are given on a $\delta(\mathrm{ppm})$ scale using TMS as internal standard. The 2D NMR experiments (HSQC, HMBC, COSY) were performed using standard Bruker pulse sequences. High-resolution ESI mass spectra were measured on a Thermo Scientific LTQ Orbitrap Velos mass spectrometer (Thermo Fisher Scientific, Bremen, Germany). Low-resolution EI mass spectra were measured on a Thermo Electron Corporation DSQ mass spectrometer (Thermo Electron Corporation, Austin, TX, USA) using a Direct-Exposure Probe (Thermo Electron Corporation, Austin, TX, USA). 
Normal- and reversed-phase column chromatography separations were performed with Kieselgel Si 60 (Merck, Darmstadt, Germany) and Kieselgel RP-18 (Merck, Darmstadt, Germany), respectively. HPLC separations were conducted on a Waters 600 liquid chromatography pump (Waters, Milford, MA, USA) with a Waters 410 refractive index detector (Warers, Milford, MA, USA), using a Kromasil $100 \mathrm{C}_{18}(250 \mathrm{~mm} \times 8 \mathrm{~mm}$ i.d.) column (MZ-Analysentechnik GmbH, Mainz, Germany). TLC was performed with Kieselgel $60 \mathrm{~F}_{254}$ aluminum plates (Merck, Darmstadt, Germany) and spots were detected after spraying with $15 \% \mathrm{H}_{2} \mathrm{SO}_{4}$ in $\mathrm{MeOH}$ reagent and heating at $100{ }^{\circ} \mathrm{C}$ for $1 \mathrm{~min}$.

\subsection{Biological Material}

The bacterial strain BI0048 was isolated from the inner tissues of the red alga L. glandulifera, collected in Zoumberi bay, south of Nea Makri, Attiki, Greece in November of 2009 and was identified as $S$. ambofaciens based on comparison of its 16S rRNA sequence with data from the Genbank database of the National Center for Biotechnology Information (NCBI) using BLAST (Basic Local Alignment Search Tool) (GenBank accession number EU593561). The strain has been deposited at the strain collection/microbank of the Department of Pharmacognosy and Chemistry of Natural Products, Faculty of Pharmacy, National and Kapodistrian University of Athens.

\subsection{Fermentation, Extraction and Isolation}

The bacterial strain BI0048 was streaked from a glycerol stock onto a freshly prepared agar plate containing a seawater-based $(\mathrm{A} 1 \mathrm{BFe}+\mathrm{C})$ medium $(10 \mathrm{~g}$ starch, $4 \mathrm{~g}$ yeast extract, $2 \mathrm{~g}$ peptone, $1 \mathrm{~g}$ $\mathrm{CaCO}_{3}, 0.1 \mathrm{~g} \mathrm{KBr}$, and $0.04 \mathrm{~g} \mathrm{Fe}_{2}\left(\mathrm{SO}_{4}\right)_{3} 5 \mathrm{H}_{2} \mathrm{O}$ per liter of filtered seawater) [18]. After sufficient growth of the bacterial strain was observed, mycelia were picked from the agar plate and were inoculated into $250 \mathrm{~mL}$ flasks containing $100 \mathrm{~mL}$ of the same seawater-based medium that were incubated at $37{ }^{\circ} \mathrm{C}$ for 4 days while shaking at $130 \mathrm{rpm}$ in an orbit shaker. Subsequently, the starter cultures were inoculated into 2 or $3 \mathrm{~L}$ flasks containing 1 or $1.5 \mathrm{~L}$ of the same seawater-based medium $(10 \%$ $v / v$ inoculum), respectively, to a total of $21 \mathrm{~L}$ of liquid medium, that were incubated at $37^{\circ} \mathrm{C}$ for 8 days while shaking at $130 \mathrm{rpm}$ in an orbit shaker. At the end of the fermentation period, Amberlite XAD-7HP resin (Sigma-Aldrich, St. Louis, MO, USA) $(20 \mathrm{~g} / \mathrm{L})$ was added to each flask to adsorb extracellular metabolites. The culture and resin were shaken overnight at low speed. The resin and cell mass were collected by filtration through cheesecloth and washed with deionized water to remove salts. The resin, cell mass and cheesecloth were then extracted for $2 \mathrm{~h}$ with $\mathrm{Me}_{2} \mathrm{CO}(6 \mathrm{~L})$. Filtration of the extract and removal of the solvent under vacuum at $40{ }^{\circ} \mathrm{C}$ afforded a solid residue $(12.5 \mathrm{~g})$ that was subjected to reversed-phase vacuum column chromatography, using $\mathrm{H}_{2} \mathrm{O}$ with increasing amounts of $\mathrm{MeOH}$, followed by $\mathrm{MeOH}$ with increasing amounts of $\mathrm{CH}_{2} \mathrm{Cl}_{2}$ as the mobile phase, to yield thirteen fractions (A-M). Fractions $\mathrm{B}, \mathrm{C}$ and $\mathrm{D}$ were combined $\left(0-30 \% \mathrm{MeOH}\right.$ in $\mathrm{H}_{2} \mathrm{O}, 2.33 \mathrm{~g}$ ) and further fractionated by normal-phase vacuum column chromatography, using EtOAc with increasing amounts of $\mathrm{MeOH}$ as the mobile phase, to afford thirteen fractions (B1-B13). Fractions B1-B6 (0-25\% $\mathrm{MeOH}$ in EtOAc, $368.9 \mathrm{mg}$ ) were repetitively subjected to reversed-phase HPLC, using $\mathrm{MeOH} / \mathrm{H}_{2} \mathrm{O}$ (60:40) as eluant, to yield $\mathbf{3}(4.6 \mathrm{mg}), \mathbf{4}(5.1 \mathrm{mg}), \mathbf{5}(20.8 \mathrm{mg}), \mathbf{6}(1.3 \mathrm{mg}), \mathbf{7}(19.1 \mathrm{mg}), \mathbf{8}(1.6 \mathrm{mg})$, benzoic acid $(0.7 \mathrm{mg})$, hydrocinnamic acid $(13.1 \mathrm{mg})$ and $(E)$-cinnamic acid $(2.4 \mathrm{mg})$. Fractions $\mathrm{E}, \mathrm{F}$ and $\mathrm{G}$ were combined $\left(40-70 \% \mathrm{MeOH}\right.$ in $\mathrm{H}_{2} \mathrm{O}, 0.93 \mathrm{~g}$ ) and further fractionated by normal-phase gravity column chromatography, using $\mathrm{CH}_{2} \mathrm{Cl}_{2}$ with increasing amounts of $\mathrm{MeOH}$ as the mobile phase, to afford twenty-five fractions (E1-E25). Fraction $\mathrm{E} 4\left(5 \% \mathrm{MeOH}\right.$ in $\left.\mathrm{CH}_{2} \mathrm{Cl}_{2}, 122.0 \mathrm{mg}\right)$ was further fractionated by normal-phase vacuum column chromatography, using c-Hex with increasing amounts of EtOAc as the mobile phase, to afford twelve fractions (E4a-E41), among which fraction E4c was identified as 9 (45.8 mg). Fractions E4d (35-40\% EtOAc in c-Hex, $23.1 \mathrm{mg}$ ) and E4e (40-50\% EtOAc in c-Hex, $17.0 \mathrm{mg})$ were separately and repetitively subjected to reversed-phase $\mathrm{HPLC}$, using $\mathrm{MeOH} / \mathrm{H}_{2} \mathrm{O}$ (100:0 to 75:25) as eluant, to yield $\mathbf{1}(1.2 \mathrm{mg}), \mathbf{2}(6.6 \mathrm{mg}), \mathbf{9}(5.1 \mathrm{mg})$ and $\mathbf{1 0}(3.8 \mathrm{mg})$. Fraction $\mathrm{E} 5\left(5 \% \mathrm{MeOH}\right.$ in $\mathrm{CH}_{2} \mathrm{Cl}_{2}$, $134.0 \mathrm{mg}$ ) was further fractionated by reversed-phase vacuum column chromatography, using $\mathrm{H}_{2} \mathrm{O}$ with increasing amounts of $\mathrm{MeOH}$ as the mobile phase, to afford eight fractions (E5a-E5h). Fractions 
E5a and E5b were combined ( $30-40 \% \mathrm{MeOH}$ in $\mathrm{H}_{2} \mathrm{O}, 54.6 \mathrm{mg}$ ) and purified by reversed-phase HPLC, using $\mathrm{MeOH} / \mathrm{H}_{2} \mathrm{O}(50: 50)$ as eluant, to yield 7 (10.6 mg). Fractions E13 and E14 were combined (13-15\% $\mathrm{MeOH}$ in $\mathrm{CH}_{2} \mathrm{Cl}_{2}, 66.0 \mathrm{mg}$ ) and further fractionated by reversed-phase vacuum column chromatography, using $\mathrm{H}_{2} \mathrm{O}$ with increasing amounts of $\mathrm{MeOH}$ as the mobile phase, to afford four fractions (E13a-E13d) that were repetitively subjected to reversed-phase HPLC, using $\mathrm{MeOH} / \mathrm{H}_{2} \mathrm{O}$ (80:20 to 40:60) as eluant, to yield $\mathbf{5}(28.7 \mathrm{mg})$.

Zoumbericin A (1): Colorless oil; $[\alpha]_{\mathrm{D}}^{20}+18.75$ (c 0.05, $\left.\mathrm{CHCl}_{3}\right)$; UV $\left(\mathrm{CHCl}_{3}\right) \lambda_{\max }(\log \varepsilon) 258$ (4.04), 282 (3.91) nm; IR (thin film) $v_{\max } 3246,2918,2850,1687,1561,1460,1250 \mathrm{~cm}^{-1} ;{ }^{1} \mathrm{H}$ and ${ }^{13} \mathrm{C}$ NMR data, see Table 1; HRESIMS $m / z 335.0928[\mathrm{M}-\mathrm{H}]^{-}$(calcd. for $\mathrm{C}_{20} \mathrm{H}_{15} \mathrm{O}_{5}, 335.0925$ ).

Zoumbericin B (2): Colorless oil; $[\alpha]_{\mathrm{D}}^{20}+15.0\left(c 0.09, \mathrm{CHCl}_{3}\right)$; UV $\left(\mathrm{CHCl}_{3}\right) \lambda_{\max }(\log \varepsilon) 283$ (3.69) nm; IR (thin film) $v_{\max } 3307,2918,2850,1688,1561,1456,1249 \mathrm{~cm}^{-1} ;{ }^{1} \mathrm{H}$ and ${ }^{13} \mathrm{C}$ NMR data, see Table 1; HRESIMS $m / z 231.0660[\mathrm{M}-\mathrm{H}]^{-}$(calcd. for $\mathrm{C}_{13} \mathrm{H}_{11} \mathrm{O}_{4}, 231.0663$ ).

Germicidin K (3): Colorless oil; $[\alpha]_{\mathrm{D}}^{20}+16.15\left(c\right.$ 0.09, $\left.\mathrm{CHCl}_{3}\right)$; UV $\left(\mathrm{CHCl}_{3}\right) \lambda_{\max }(\log \varepsilon) 274$ (3.59) nm; IR (thin film) $v_{\max } 2970,2934,2878,1742,1369,1220 \mathrm{~cm}^{-1} ;{ }^{1} \mathrm{H}$ and ${ }^{13} \mathrm{C}$ NMR data, see Table 2; HRESIMS $m / z 211.0975[\mathrm{M}-\mathrm{H}]^{-}$(calcd. for $\mathrm{C}_{11} \mathrm{H}_{15} \mathrm{O}_{4}, 211.0976$ ).

Germicidin L (4): Colorless oil; $[\alpha]_{\mathrm{D}}^{20}+25.5\left(c 0.07, \mathrm{CHCl}_{3}\right)$; UV $\left(\mathrm{CHCl}_{3}\right) \lambda_{\max }(\log \varepsilon) 274$ (3.49) nm; IR (thin film) $v_{\max } 2971,2918,2851,1737,1367,1218 \mathrm{~cm}^{-1} ;{ }^{1} \mathrm{H}$ and ${ }^{13} \mathrm{C}$ NMR data, see Table 2; HRESIMS $m / z$ 197.0818 [M - H] $]^{-}$(calcd. for $\mathrm{C}_{10} \mathrm{H}_{13} \mathrm{O}_{4}, 197.0819$ ).

\subsection{Evaluation of Antibacterial Activity}

The antibacterial activity of compounds 1-10 was evaluated against the epidemic methicillin-resistant S. aureus strain EMRSA-15, the S. aureus strain SA1199B that possesses the gene encoding the NorA quinolone efflux protein and the E. coli strain NCTC-10418 as previously described [19].

\subsection{Evaluation of Cytotoxic Activity}

The cytotoxic activity of compounds 1-10 was evaluated against the MCF7 (breast adenocarcinoma) and A549 (lung carcinoma) cancer cell lines as previously described [20].

\section{Conclusions}

The chemical investigation of the organic extract of the fermentation of the endophytic strain S. ambofaciens BI0048, isolated from the red alga L. glandulifera, resulted in the isolation and structure elucidation of four new $\alpha$-pyrone polyketides, namely zoumbericin $A(1)$, zoumbericin $B(2)$, germicidin $K$ (3) and germicidin L (4). The evaluation of the antibacterial and cytotoxic activities of the new natural products 1-4 and the previously reported metabolites 5-10 against two multidrug-resistant strains of $S$. aureus and one strain of E. coli, as well as two human cancer cell lines, respectively, did not reveal any worth-nothing levels of bioactivity.

Acknowledgments: This work was partially supported by the project ARISTEIA-2587 "BIOMARACT", which was implemented under the "ARISTEIA" Action of the Operational Programme "EDUCATION AND LIFELONG LEARNING" and was co-funded by the European Social Fund (ESF) and National Resources. The authors thank A. Makris (Institute of Applied Biosciences/CERTH, Thessaloniki, Greece) for the identification of the bacterial strain BI0048, as well as E. Mavrogonatou and D. Kletsas (Institute of Biosciences and Applications, NCSR "Demokritos", Athens, Greece) for the evaluation of the cytotoxic activity. E.R. gratefully acknowledges the Special Account for Research Grants of the National Technical University of Athens for a Ph.D fellowship.

Author Contributions: Efstathia Ioannou and Vassilios Roussis conceived and designed the experiments; Enikő Rab performed the experiments; Efstathia Ioannou, Vassilios Roussis and Enikő Rab analyzed the data; Efstathia 
Ioannou, Vassilios Roussis and Dimitrios Kekos contributed reagents/materials/analysis tools; Efstathia Ioannou wrote the paper.

Conflicts of Interest: The authors declare no conflict of interest. The funding sponsors had no role in the design of the study; in the collection, analyses, or interpretation of data; in the writing of the manuscript, and in the decision to publish the results.

\section{References}

1. Knight, V.; Sanglier, J.-J.; DiTullio, D.; Braccili, S.; Bonner, P.; Waters, J.; Hughes, D.; Zhang, L. Diversifying microbial natural products for drug discovery. Appl. Microbiol. Biotechnol. 2003, 62, 446-458. [CrossRef] [PubMed]

2. Bérdy, J. Bioactive microbial metabolites. J. Antibiot. 2005, 58, 1-26. [CrossRef] [PubMed]

3. Demain, A.L.; Sanchez, S. Microbial drug discovery: 80 years of progress. J. Antibiot. 2009, 62, 5-16. [CrossRef] [PubMed]

4. Barka, E.A.; Vatsa, P.; Sanchez, L.; Gaveau-Vaillant, N.; Jacquard, C.; Klenk, H.-P.; Clément, C.; Ouhdouch, Y.; van Wezel, G.P. Taxonomy, physiology, and natural products of Actinobacteria. Microbiol. Mol. Biol. Rev. 2016, 80, 1-43. [CrossRef] [PubMed]

5. Piel, J.; Hoang, K.; Moore, B.S. Natural metabolic diversity encoded by the enterocin biosynthesis gene cluster. J. Am. Chem. Soc. 2000, 122, 5415-5416. [CrossRef]

6. Xiang, L.; Kalaitzis, J.A.; Nilsen, G.; Chen, L.; Moore, B.S. Mutational analysis of the enterocin Favorskii biosynthetic rearrangement. Org. Lett. 2002, 4, 957-960. [CrossRef] [PubMed]

7. Miyairi, N.; Sakai, H.-I.; Konomi, T.; Imanaka, H. Enterocin, a new antibiotic-taxonomy, isolation and characterization. J. Antibiot. 1976, 29, 227-235. [CrossRef] [PubMed]

8. Seto, H.; Sato, T.; Urano, S.; Uzawa, J.; Yonehara, H. Utilization of ${ }^{13} \mathrm{C}-{ }^{13} \mathrm{C}$ coupling in structural and biosynthetic studies. VII. The structure and biosynthesis of vulgamycin. Tetrahedron Lett. 1976, 17, 4367-4370. [CrossRef]

9. Sitachitta, N.; Gadepalli, M.; Davidson, B.S. New $\alpha$-pyrone-containing metabolites from a marine-derived actinomycete. Tetrahedron 1996, 52, 8073-8080. [CrossRef]

10. Petersen, F.; Zähner, H.; Metzger, J.W.; Freund, S.; Hummel, R.-P. Germicidin, an autoregulative germination inhibitor of Streptomyces viridochromogenes NRRL B-1551. J. Antibiot. 1993, 46, 1126-1138. [CrossRef] [PubMed]

11. Pouchert, C.J.; Behnke, J. The Aldrich Library of ${ }^{13} \mathrm{C}$ and ${ }^{1} \mathrm{H}$ FT NMR Spectra, 1st ed.; Aldrich Chemical Company, Inc.: Milwaukee, WI, USA, 1993; Volume 2, pp. 985, 1043, 1063.

12. Cutignano, A.; Fontana, A.; Renzulli, L.; Cimino, G. Placidenes C-F, novel $\alpha$-pyrone proprionates from the Mediterranean sacoglossan Placida dendritica. J. Nat. Prod. 2003, 66, 1399-1401. [CrossRef] [PubMed]

13. McGlacken, G.P.; Fairlamb, I.J.S. 2-Pyrone natural products and mimetics: Isolation, characterization and biological activity. Nat. Prod. Rep. 2005, 22, 369-385. [CrossRef] [PubMed]

14. Bhat, Z.S.; Rather, M.A.; Maqbool, M.; Lah, H.U.L.; Yousuf, S.K.; Ahmad, Z. $\alpha$-Pyrones: Small molecules with versatile structural diversity reflected in multiple pharmacological activities-An update. Biomed. Pharmacother. 2017, 91, 265-277. [CrossRef] [PubMed]

15. Kawashima, A.; Seto, H.; Kato, M.; Uchida, K.; Otake, N. Preparation of fluorinated antibiotics followed by ${ }^{19}$ F NMR spectroscopy. I. Fluorinated vulgamycins. J. Antibiot. 1985, 38, 1499-1505. [CrossRef] [PubMed]

16. Babczinski, P.; Dorgerloh, M.; Löbberding, A.; Santel, H.-J.; Schmidt, R.R.; Schmitt, P.; Wünsche, C. Herbicidal activity and mode of action of vulgamycin. Pestic. Sci. 1991, 33, 439-446. [CrossRef]

17. Xu, Z.; Ding, L.; Hertweck, C. A branched extender unit shared between two orthogonal polyketide pathways in an endophyte. Angew. Chem. Int. Ed. 2011, 50, 4667-4670. [CrossRef] [PubMed]

18. Bugni, T.S.; Woolery, M.; Kauffman, C.A.; Jensen, P.R.; Fenical, W. Bohemamines from a marine-derived Streptomyces sp. J. Nat. Prod. 2006, 69, 1626-1628. [CrossRef] [PubMed] 
19. Dimou, M.; Ioannou, E.; Daskalaki, M.G.; Tziveleka, L.A.; Kampranis, S.C.; Roussis, V. Disulfides with anti-inflammatory activity from the brown alga Dictyopteris membranacea. J. Nat. Prod. 2016, 79, 584-589. [CrossRef] [PubMed]

20. Mavrogonatou, E.; Eliades, T.; Eliades, G.; Kletsas, D. The effect of triethylene glycol dimethacrylate on p53-dependent G2 arrest in human gingival fibroblasts. Biomaterials 2010, 31, 8530-8538. [CrossRef] [PubMed] 